\title{
Effect of IFRS Adoption on Corporate Performance Measurement: Analysis of Japanese Manufacturing Companies
}

\author{
Yuta Hoshino ${ }^{1,2}$ \\ ${ }^{1}$ School of Modern Management, Sugiyama Jogakuen University, Japan \\ ${ }^{2}$ Graduate School of Economics, Nagoya City University, Japan
}

Copyright $\mathrm{O} 2017$ by authors, all rights reserved. Authors agree that this article remains permanently open access under the terms of the Creative Commons Attribution License 4.0 International License

\begin{abstract}
The International Financial Reporting Standards (IFRS) are becoming the leading principles and a special driver for the convergence of financial and management accounting in over 130 countries including the voluntary adoption. The purpose of this study is to examine the impact of the adoption of IFRS on management accounting. More specifically, this study investigates the differences in the importance of strategy goals, and financial and nonfinancial measures that have changed after its adoption. The results of a questionnaire survey conducted on Japanese manufacturing companies indicate that the effects of respondent firms provide with management accounting practices and techniques before and after the adoption of IFRS. My findings suggest that there seem to be considerable differences in the importance of strategy goals, and financial and nonfinancial measures before and after IFRS adoption.
\end{abstract}

Keywords IFRS, Management Accounting, Strategy Goals, Financial Measures, Nonfinancial Measures

\section{JEL Classification: M41}

\section{Introduction}

The purpose of this paper is to clarify the changes between before and after adoption of the International Financial Reporting Standards (IFRS)[1] by an enterprise, on strategic goals and financial performance measurement. IFRS adoption may have a significant effect on the business management basis of Japanese companies, such as preparation of the annual report by profit disclosure using comprehensive income, retention of cross-shareholdings, business strategy such as mergers and acquisitions (M\&A), improvement of the business process, and renewal of the information system.

The current trend of accounting internationalization worldwide has evolved by converging the accounting standards of each country with the International Accounting Standards toward a direction that promotes and encourages IFRS adoption [2, 3]. In the section of "purpose of the constitution" in the IFRS foundation, it was newly specified in March 2010, that IFRS was also adopted through convergence [4]. ${ }^{1}$

However, the movement toward IFRS adoption in Japan is still very slow. In June 2009, the interim report by the Financial Services Agency in Japan was announced, and it was leaning toward IFRS adoption. Consequently, the consciousness of the enterprise rapidly increased. The enterprise, which begins to move for early adoption has also appeared. ${ }^{2}$ Then, in the schedule, whether or not it imposed the adoption by the listed enterprise in 2012 would be finally judged, and the directivity of the duty also worked out the adoption in 2015 or 2016. However, the road map to IFRS adoption by Japanese enterprises is not yet clarified, although the Accounting Standards Board of Japan (ASBJ) and the International Accounting Standards Board (IASB) keep the regular consultation afterwards. The fact is that the presentation of the securities reports by IFRS has still not been accepted, even though the convergence is progressing in Japan [5].

It was opined that people of the affirmative side should adopt IFRS to all listed enterprises at the beginning 2009, but

1 IASC $(2010,5)$. The opening process of this article of association had been approved in January 2010, and was brought into effect in March 2010 by the International Accounting Standards Board (IASB). It was then revised in December 2010

2 Nihon Dempa Kogyo Co., Ltd., of the crystal device company, voluntarily applied international accounting standards to their accounts for the year ending March 2010. Afterwards, it was made public that Sumitomo Corporation and HOYA in March 2011; Nippon Sheet Glass and Japan Tobacco in March 2012; the DNA, Anritsu, and SBI Holdings in March 2013; Rakuten, Chugai Pharmaceutical, and Asahi Glass Company Limited in December 2013; and Softbank and Marubeni Corporation in March 2014, etc. apply voluntarily. 
it remains an idea limited to a part of listed enterprises at present $[6,7] .^{3}$ After all, it must be recognized that the directivity of the discussion for IFRS adoption is still not clarified. On the other hand, countries (declaring country is contained) where IFRS is being adopted or converged already include over 130 nations. The accounting standards of the world surely approach the direction of IFRS introduction, if the fact is considered, and it will only be a matter of time when the adoption starts in Japanese enterprises. Therefore, it can be easily considered that it does not become advantageous for the performance measurement of Japanese enterprises at all, even if IFRS adoption was delayed slightly.

Of course, the effect of IFRS adoption widely reaches not only changes in the preparation of the annual reports but also reviews of the financial measures as an evaluation base and the business process as a means of business management. In short, due to the changes in the financial measures after IFRS adoption, the effect on corporate performance is not small at all. It is proven that the financial performance of Japanese companies fluctuates, considering the international convergence of accounting standards as an opportunity. There exists research [8] that indicates that this fact may significantly affect the dividend behavior and investment behavior of Japanese companies. ${ }^{4}$ After all, though the business process reform of such enterprises is the necessary for IFRS adoption, the global and common evaluation measure is possible, and as a result, the effect of the merit that M\&A strategy becomes easy, is important. The content of the financial report measured by IFRS adoption is greatly useful for the management, having interest in future results rather than past performance, as the judgment material of the performance evaluation.

IASB has carried out the idea under the expected purpose, and have undertaken the mission of finally fulfilling the following tasks for global investors; (1) to offer high quality, transparent, and practicable information through the international accounting standards, (2) to promote utilization and strict adoption of the accounting standards, and (3) to harmonize the accounting standards of each country and IFRS with high quality. ${ }^{5}$ Therefore, IFRS adoption is important not only for disclosure to outside stakeholders but also the inside management.

Further, this paper examines the effect of adoption on the management accounting technique, while the problems of IFRS adoption are investigated. IFRS adoption is supposed

3 Accounting's editorial staff $(2012,69)$. Tsujiyama $(2012,52)$ assumes the concrete project that IASB and FASB advance to a meta-rule of a standard making for the internationalization of accounting and the idea of a standard setting, and explains the structure.

4 Kagaya $(2012,42-43 \& 46-52)$. In his thesis, it is proven that it has a negative influence on the investment behavior of Japanese firms when the introduction of IFRS focuses on the change of sustainable cash flow at the profit attribute, especially the future, and the change of the profit is large.

5 IASB (2004). The purpose of first IASC was very simple, having provided the organization and the function of the foundation rather than movement for the convergence. to significantly affect the strategic objectives, and financial and nonfinancial measures [9]. Therefore, by the internationalization of the accounting standards, the situation of importance and change of the availability is examined, and implies a meaning that is important for performance measurement and disclosure of future companies. Based on such problem recognition, this paper carries out a mail questionnaire survey for Japanese companies. The effects of IFRS adoption on the management accounting technique are demonstratively analyzed.

\section{Research Questions and Related Literature}

\subsection{Verification Subjects with IFRS Adoption}

IFRS adoption has several merits: (1) it is undertaken by stock investment and merchandising exceeding countries and regions; (2) since the appropriation rule of sales and profit differs, it is not possible to offer judgment material that can be compared internationally; and (3) the evaluation and reliability of the enterprise increases, when the common measures for the enterprise are adopted. However, it also has some demerits: (1) it is exposed to the severe evaluation of global investors; (2) the individual judgment is obtained based on the principle; and (3) time and cost depend on the conversion to the new standard from the existing one.

On the other hand, our researchers need to bear in mind the effects of IFRS adoption on Japanese companies: (1) governance of consolidated accounting; (2) improvement of the internal control system resulting from the disclosure of information strengthening; (3) the substantiality of intangible assets' disclosure; and (4) strengthening of accounting literacy $[10] .^{6}$

By the introduction of IFRS, a large change is anticipated for management control through global motivation of the increase of the opportunities for transactions and investment activities in which enterprises trade in foreign countries. Therefore, it is important to establish the performance measures for global consolidated accounting. On the other hand, statement of financial condition, statement of comprehensive income, and statement of cash flows, etc. will be newly used, if IFRS is applied, and it becomes impossible to correspond by the traditional financial performance measures used currently. Since the principles of accounting may change if IFRS is introduced, numerical values, such as sales revenues, expense, assets, and liabilities, also change. As a result, it is unclear how the valuation levels of financial measures of Return on equity (ROE) and Return on assets (ROA), etc. change. Then, to correspond to IFRS, the accounting evaluation system by which the top management

6 Hoshino (2012, 43). Refer to this thesis for the reason why international accounting standards are focused on, and the features, etc. 
can follow the performances of each department is requested to be maintained. Specifically, it is necessary to research management accounting by confirming how the relation between the management action and the performance measurement system of the firm changes after introducing IFRS, and collecting the data of the firm.

First, the performance measurement system should become one management accounting system to compose a new management technique for strengthening the industrial and global competitiveness only because of disclosure of the financial results. It is necessary to clarify the measures that should not only construct a useful management accounting system for the financial reporting of outside stakeholders, but also to support a variety of management processes, and to construct a useful performance evaluation system for motivating management's organizational behavior in Japan that may adopt IFRS in the near future. Moreover, if new "statement of financial performance" by non-financial information can be presented, it will become useful material for investors. In that sense, it seems that the influence of IFRS introduction on the performance appraisal system in Japanese companies will grow significantly in the future. Specifically, it is important to understand how the introduction of IFRS can unite the accounting business processes of Japanese companies and overseas group companies. Further, it is necessary to confirm how the performance measurement index changes by the uniformity.

It is necessary to review the management accounting system including budget management and a mid/long-term managerial planning, etc. because the standard of measurement for sales and profit is different between such a standard and the Japanese standard after applying IFRS. Therefore, after introducing IFRS, it is necessary to do the decision-making according to the information evaluated by new measures with stakeholders such as investors and stockholders because the performance so far will be evaluated by different financial measures. In addition, the results of a survey conducted indicate that in European firms that apply IFRS, 45.7 percent of the companies have increased with gross profit and 22.0 percent with net assets. Moreover, the following results of the survey reported how the management strategy changed: (1) 20.3 percent companies came to value the property efficiency thoroughly, (2) 13.6 percent companies became positive in M\&A, and (3) companies that act rashly during business withdrawal constituted 3.4 percent $[11]^{7}$

Thus, the introduction of IFRS makes it possible to manage the entire business of the global companies by standardizing the accounting rule both in the headquarters and in the overseas group companies. Of course, financial numerical values collected from each company in an

7 Nikkei Business (2010, 22 and 32). A numerical value concerned is based on the joint investigation by the Nikkei business magazine and Audit Corporation [Avantia]. This investigation is the result of the responses from 116 of 540 companies listed in Euronext of Paris. overseas group should construct a new accounting measurement system about the budget management and the performance evaluation of the headquarters in conformity with it because it is calculated by the IFRS standard. Further, after introducing IFRS, the viewpoint of how the business can be developed in the future becomes more important than past performance in globalization.

Further, it is necessary to examine the aspect of the research here valuing the following aspects: (1) change of management strategic goals and accounting systems, (2) shift from net income to comprehensive income, and (3) conversion from income expense approach to assets liability approach. Comprehensive income is the amount of the change under the expectation of the change of unrealized profits and losses related to securities and derivatives (variance of the estimate), and the foreign currency transaction adjustment, etc. was added to the net income here. In other words, the comprehensive income looks considerably different from the net income shown as income from operating activities in the last line of the income statement (bottom line). Since saleable value such as unused land is included in the comprehensive income that shows the change of net assets, Japanese companies that have been traditionally valuing sales and profit might have a sense of incompatibility. However, because the net income (profit or loss) is connected with "earnings manipulation" involving increasing the income by selling off the cross-holding of shares if the performance deteriorates, that forms the ground for introducing comprehensive income.

Thus, two hypotheses are defined as verification subjects in this paper. If the strategy and the evaluation rule are different regardless of the introduction of IFRS, the following hypothesis is derived.

Hypothesis 1: There is a difference in the degree (use level) valued between a strategic objective and, financial, and nonfinancial measures.

On the other hand, when the profit and approach are made assuming conversion by introducing IFRS, another hypothesis is derived.

Hypothesis 2: There is a difference in the degree of valuing strategic goals, financial measures, and non-financial measures when comparing it before and after the introduction of IFRS.

In this paper, first, these hypotheses 1 and 2 are together set as an alternative hypothesis (H1). Second, strategic goals, financial measures, and nonfinancial measures are classified into three null hypotheses $(\mathrm{H} 0)$ respectively in Chapter 4, and finally, it is given official approval whether $\mathrm{H} 0$ is dismissed respectively. In the next section, this study examines the content of prior research that examined the effect of the application of IFRS on management accounting concerning such problems.

\subsection{Related Prior Research}

This section will examine the domestic and foreign prior 
research studying the influence that IFRS introduction exerts on achievement measurement.

There are neither too many applications of IFRS nor research on its relation with management accounting. First, this chapter enumerates an overseas prior research. The research of Cohen and Karatzimas (2013) [12] was regarding the influence that IFRS adoption exerts on management accounting. They examined the use of financial data of companies and the influence on the management accounting practice after it converts to IFRS. Specifically about companies in Greece, they clarify how the interaction between the manager's decision-making, internal reports, and external reports changes. This shows that the more the financial data is used for internal reporting purpose, the more the use extends to the management accounting purpose like decision-making and performance evaluation. ${ }^{8}$

On the other hand, Prochazka (2009) [13] examines the influence of IFRS introduction on financial and management accounting in the Czech Republic. He points out that we cannot prevent IFRS from improving the quality of financial reporting, and making the management accounting high-quality as the main standard besides financial accounting as the base. ${ }^{9}$ Thus, he indicates that the coexistence between management and financial accounting will subsequently become inevitable. Previous research by Jones and Luther (2005) [14] led them to analyze German companies based on actual observation.

In addition, though it is not a research in the area of management accounting, the profit attribute changes by introducing IFRS, and in the enterprise that adopts performance-based incentive systems, there is a research case that changes in financial performance by it influences even management compensation. Ozkan et al. (2012) [15] can be considered one of the related research studies. They verify the influence on pay-for-performance sensitivity $(\mathrm{PPS})^{10}$ and relative performance evaluation (RPE) by IFRS adoption in the European Union (EU), and research the importance given to the utility of the account information in the management compensation contract. ${ }^{11}$

Further, the feature of the profit concept of IFRS is to convert from net income (profit or loss for the period) to comprehensive income. In other words, there is a possibility that the technique of profit management changes greatly

8 Cohen and Karatzimas (2012). The implication concerning the decision-making and the interaction on influence to the business of management accounting after IFRS is introduced here, especially between internal and external reports is useful.

9 Prochazka (2009). He analyzes the influence given to net income between the Czech Republic accounting standards and the IFRS. In the supplement, he analyzes the differences between the Czech Republic accounting standards and IFRS based on the data of the annual report of 2004-2005, and the case with 10 companies with revenue, net income, assets, equity capital, and liabilities analyzed.

10 Here pay-for-performance sensitivity (PPS) is a regression coefficient of the model shown by the sensitivity approach, and shows strength that the reward synchronizes with the corporate performance by the coefficient.

11 Ozkan et al. (2012). They verified the influence given to the enterprise that did the administrative by using data from 2002 to 2008 excluding 2005 when IFRS had been compelling applied in Europe. (management according to the segment, etc.) by using comprehensive income. One of the features of IFRS is the asset-liability approach. According to Shimizu (2011) [16], IFRS suggests the conversion "from management that values the flow to management that values the stock." ${ }^{12}$ Certainly, it tends for the statement of financial position that calculates ROE and ROA, etc. as a financial measure to value, and to be adopted as more than a current balance sheet because the importance of the statement of financial position increases. Therefore, this statement of financial position will also be used as a main Key Performance Indicator according to the segment, in the future. In addition, Kawano (2010) [17] points out that performance measures such as operating profit, net income, ROE, ROA, economic value added (EVA), and earnings before interests, taxes, depreciation and amortization (EBITDA) cannot avoid the influence by the difference with a Japanese standard by IFRS introduction. ${ }^{13}$ On the other hand, like Kanagaretnam et al. (2009) [18], there are some researchers who point out that comprehensive income correlates to stock prices or return, and net income is a forecast factor of the profit in the future as well, thus the former cannot necessarily fix the domination. ${ }^{14}$

The possibility that the measure of the performance evaluation changes greatly is incontrovertible if it shifts from "net income" of the dominant constraint to "comprehensive income" that is the management result of the enterprise that reflects the market value of the investor. Since the measure of Japanese standards and that of IFRS are different, sales and profit amounts are different. As a result, how performance measures that construct new management accounting systems of budget management, managerial planning, and performance evaluation, etc. within the framework of IFRS and obtains it is used, becomes important. Thus, it is necessary to change to the management technique for taking a management action different from the situation to date how for the management accounting related to the decision making and the performance evaluation to be going to achieve the strategic goals as long as "comprehensive income" becomes the measure of the profitability by introducing IFRS in the future.

Thus, as Shimizu (2011) [16] suggests, by introducing regulations of IFRS, it is natural that accounting standards should be converted from management that values flow to one that values the stock. It is because the management

12 Shimizu $(2011,105)$. He points out that the management method cannot help changing by the change in the concept of this income (p.106).

13 Kawano $(2010,28)$. This thesis takes the standpoint that the business objective does not change at once because it does not aim at it alone even if the income concept changes into the comprehensive income, although the introduction of IFRS influences it.

14 Kanagaretnam et al. (2009). Canadian accounting standards set by the Accounting Standards Board (AcSB) in Canada are influenced by IASB and FASB, and these Canadian standards have features harmonized with IASB and FASB. Though it is necessary to understand after that is recognized, all the same, they have verified whether the stock market offers increased value relevance information, which exceeded the traditional historical cost basis approach on companies that report the comprehensive income by applying the accounting policy of Canada. 
method changes by changing from the income-expense approach that the profit concept values the profit and loss statement to the asset-liability approach that values the balance sheet. On the other hand, Sonoda (2011) [19] points out that IFRS has the possibility of not only influencing the accounting side but also the management side, for instance, employees' working changes along with the change of performance evaluation measures. ${ }^{15}$ In addition, Sakurai (2012) [20] insists that the bottom line can become the net income for manager's performance evaluation according to the strategy and the decision making though it will shift from the net income that a Japanese standard has caught up to now to the comprehensive income by the IFRS introduction. ${ }^{16}$ As Ueno (2010) [21] suggests, net income is the performance measure of the top management while comprehensive income is a standard of the corporate performance measures. ${ }^{17}$

\section{Sample and Inspection Method}

The survey questionnaire was mailed to 813 Japanese manufacturing companies that are listed on the first section of the Tokyo Stock Exchange, and are considered innovators and market leaders in their respective industries. The companies were grouped into 15 categories: food, apparel, chemicals, petroleum and coal products, rubber products, ceramics, steel, non-ferrous metal, metal products, machinery, electronics, transportation equipment, precision instruments, and other manufacturing industries. The questionnaires were addressed to the company controller or the manager of the accounting department. The questionnaire was administered between July 1 and 31, 2011. The completed questionnaires were returned by 65 Japanese companies, constituting a response rate of 8.0 percent. The highest industry response rate was 18.2 percent for rubber products, and the lowest was 2.8 percent for metal products. It is assumed that the response rate of companies was somewhat low because the investigation period was immediately after the great East Japan earthquake.

The survey questionnaire comprises 21 questions (31 items) relating to strategic goals, divisional organization, budgeting, capital investment, performance evaluation, and performance measurement. Specifically, this thesis analyzes strategic goals, and financial and nonfinancial measures in relation to IFRS introduction. In the next chapter, to clarify the characteristics resulting from investigating the actual

15 Sonoda $(2011,118)$. He indicated the importance of such management aspect in the process, which examines the influence of the application of IFRS on costing and management accounting.

16 Sakurai $(2012,247)$. This thesis serves as a reference concerning where the influence that IFRS exerts on management accounting is inclusively examined.

17 Ueno $(2010,191)$. This paper examines not only the problem of management accounting but also critical problems such as comprehensive income, fair value, and assets and liabilities approach, etc. regarding the process of convergence of IFRS. conditions concerning strategic goals and performance measurement in Japanese manufacturing companies, the relevant aspects will be empirically analyzed.

Regarding the inspection method, first, it is necessary to verify by the chi-square test (test of independence) whether there was a difference before the introduction of IFRS on the use level of strategic goals, financial measures, and nonfinancial measures that Japanese firms valued. That is, it was verified whether three high-rank answers had differing valuing level of strategic goals, financial measures, and non-financial measures valued before and after IFRS introduction. Second, Test (t-test) of the difference of mean value of two groups and Wilcoxon code ranking sum test are carried out based on the recovered data in order to confirm it. Moreover, use level of each item and each valuing level of strategic goals, financial measures, and nonfinancial measures valued before and after the introduction of IFRS will be qualitatively observed.

\section{Empirical Result and Analysis}

\subsection{Strategy Goals}

This paper focuses on only strategic goals, and financial and nonfinancial measures, although the content of the questionnaire comprises five sections. The strategic goals will be investigated in this Chapter. How each strategic goal was valued before IFRS adoption is shown in Table 1 based on the Likert scale ( 5 is greatly dissatisfied, 1 is greatly satisfied). The chi-square test (test of independence) was carried out to verify whether the degree of the strengthening of strategic goals of Japanese companies differs. As a result, it was confirmed that the null hypothesis "There was no difference between the valued strategic goals" was rejected, and the alternative hypothesis was significant at the one percent level and was supported.

Table 2 depicts the comparison between the answers of two questions. One question concerns choosing three high ranks of strategic goals that have been valued before IFRS introduction and the other concerns choosing three high ranks of strategic goals valued after IFRS introduction. It is shown that it is significant as a result of doing Test (t-test) of the difference of mean value of two groups with correspondence and Wilcoxon code ranking sum test based on the sample, respectively. That is, as a result of these tests, the null hypothesis "There will not be any difference in the valued strategic goals before and after the introduction of IFRS" was rejected at the five percent level of significance. Here, the t-value shows the statistic of the test of the difference of the mean of two groups, and the z-value shows the statistic of Wilcoxson test, which tests the significance. Thus, it was confirmed that the two tests were together significant at the five percent level. It is shown that there is a difference to some extent in the degree of the serious consideration of strategic goals between before and after IFRS introduction. 
The difference is caused in sales revenue and profit revenue because the rules between Japanese and IFRS standards are different. This study recognizes the differences in the management accounting techniques of budget management, managerial planning, and performance evaluation, etc. by introducing IFRS, and how the performance evaluation measures are used in addition, becomes important. Specifically, it will be assumed that comprehensive income measures of the profitability by introducing IFRS. This means that the management accounting technique related to current investment decision-making and managerial planning is converted into a technique for taking a new management activity by considering how to achieve strategic goals in the future.

Next, this section qualitatively observes Tables 1 and 2 . First, 16 kinds of strategic goals were enumerated, and the questionnaire asked how to attach importance to each goal of the enterprise by a five-stage evaluation (1-5 Likert scale) in the question investigation vote. The evaluation of each valued goal was requested to be shown by figures 1 to 5 . The result is Table 1. Moreover, regarding before and after IFRS, the questionnaire asks the respondents to rank the top three strategy goals for their firms, from among 16 managerial categories provided. Table 2 depicts these results. The main strategic goals sequentially identified from the high rank by Table 2 include growth of earnings, strengthening of $R \& D$ efficiency, sales growth, improvement of product qualities, etc. This survey questionnaire's results were opposite to the forecast that sales growth $\left(3^{\text {rd }}\right.$ rank) and growth in market share ( $7^{\text {th }}$ rank) had forecast, valuing more than the profit at first, although strategic goals of Japanese firms are unlike those of American enterprises. Therefore, this study places its focus on the ranking of growth of earnings to first rank any more though sales growth and growth in market share are also high to some degree as seen in Table 2. This is an evidence to value the managerial efficiency of the rate of profit, etc. in Japanese firms managing it. In the feature concerning this in Table 2, strengthening of R\&D ability and sales growth are ranked second and third, respectively. This is evidence suggesting that Japanese firms have improved global competitiveness through the achievement of strengthening technology and low-cost products.

When IFRS is applied, this research will emphasize that an important aspect arose especially among strategic goals that the enterprise chose to be a high rank as one example. For example, they are sales growth $\left(2^{\text {nd }}\right.$ rank from $3^{\text {rd }}$ rank $)$, return on investment $\left(4^{\text {th }}\right.$ rank from $10^{\text {th }}$ rank), return on equity $\left(11^{\text {th }}\right.$ rank from $13^{\text {th }}$ rank), and rationalization of the physical distribution system $\left(12^{\text {th }}\right.$ rank from $16^{\text {th }}$ rank), etc.

Within strategic goals, in addition, it is because of the evidence that the stockholder control was made a weakness by cross-shareholdings, that the degree of serious consideration of "capital gain of the stockholder" is low.

Table 1. Important Strategy Goals

\begin{tabular}{|c|c|c|c|c|c|c|c|}
\hline & $\begin{array}{c}\text { Greatly } \\
\text { Dissatisfied }\end{array}$ & & $\begin{array}{l}\text { Moderately } \\
\text { Satisfied }\end{array}$ & & $\begin{array}{l}\text { Greatly } \\
\text { Satisfied }\end{array}$ & & \\
\hline & 1 & 2 & 3 & 4 & 5 & No Response & Mean (S. D.) \\
\hline \multicolumn{8}{|l|}{ Number of respondent companies: 65} \\
\hline Strengthening of R\&D efficiency & $0(0.0)$ & $1(1.5)$ & $10(15.4)$ & $24(36.9)$ & $30(46.2)$ & $0(0.0)$ & $4.277(0.775)$ \\
\hline Growth of earnings & $0(0.0)$ & $0(0.0)$ & $11(16.9)$ & $21(32.3)$ & $32(49.2)$ & $1(1.5)$ & $4.262(0.916)$ \\
\hline Improvement of product quality & $0(0.0)$ & $0(0.0)$ & $10(15.4)$ & $28(43.1)$ & $27(41.5)$ & $0(0.0)$ & $4.262(0.708)$ \\
\hline Development of human resources & $0(0.0)$ & $3(4.6)$ & $13(20.0)$ & $29(44.6)$ & $19(29.2)$ & $1(1.5)$ & $3.938(0.959)$ \\
\hline Sales growth & $1(1.5)$ & $2(3.1)$ & $13(20.0)$ & $31(47.7)$ & $17(26.2)$ & $1(1.5)$ & $3.892(0.979)$ \\
\hline $\begin{array}{l}\text { Improvement of public image of } \\
\text { the company }\end{array}$ & $0(0.0)$ & $4(6.2)$ & $20(30.8)$ & $28(43.1)$ & $13(20.0)$ & $0(0.0)$ & $3.769(0.837)$ \\
\hline $\begin{array}{l}\text { Strengthening of marketing } \\
\text { capability }\end{array}$ & $0(0.0)$ & $5(7.7)$ & $17(26.2)$ & $28(43.1)$ & $14(21.5)$ & $1(1.5)$ & $3.738(0.985)$ \\
\hline Growth in market share & $1(1.5)$ & $4(6.2)$ & $15(23.1)$ & $35(53.8)$ & $9(13.8)$ & $1(1.5)$ & $3.677(0.946)$ \\
\hline Equity ratio & $3(4.6)$ & $4(6.2)$ & $26(40.0)$ & $24(36.9)$ & $8(12.3)$ & $0(0.0)$ & $3.462(0.946)$ \\
\hline Improvement of product portfolio & $1(1.5)$ & $6(9.2)$ & $24(36.9)$ & $28(43.1)$ & $4(6.1)$ & $2(3.1)$ & $3.338(0.997)$ \\
\hline Efficiency of physical distribution & $1(1.5)$ & $4(6.2)$ & $33(50.8)$ & $22(33.8)$ & $4(6.2)$ & $1(1.5)$ & $3.323(0.861)$ \\
\hline $\begin{array}{l}\text { Improvement in quality of working } \\
\text { conditions }\end{array}$ & $0(0.0)$ & $8(12.3)$ & $28(43.1)$ & $24(36.9)$ & $4(6.2)$ & $1(1.5)$ & $3.323(0.879)$ \\
\hline Efficiency of production systems & $1(1.5)$ & $5(7.7)$ & $31(47.7)$ & $24(36.9)$ & $3(4.6)$ & $1(1.5)$ & $3.308(0.858)$ \\
\hline Capital gains for stockholders & $0(0.0)$ & $9(13.8)$ & $33(50.8)$ & $18(27.7)$ & $5(7.7)$ & $0(0.0)$ & $3.292(0.799)$ \\
\hline Return on investment (ROI) & $2(3.1)$ & $8(12.3)$ & $34(52.3)$ & $17(26.2)$ & $4(6.2)$ & $0(0.0)$ & $3.200(0.845)$ \\
\hline New product ratio & $4(6.2)$ & $12(18.5)$ & $22(33.8)$ & $22(33.8)$ & $4(6.2)$ & $1(1.5)$ & $3.108(1.069)$ \\
\hline
\end{tabular}

Results of test of independence: Chi-square value $=249.7839$; Degrees of freedom=60; $p$-value $=0.000$. Cramer V=0.2463.

Significant at 1 percent level. 
Table 2. Importance of Strategy Goals between before and after IFRS Adoption

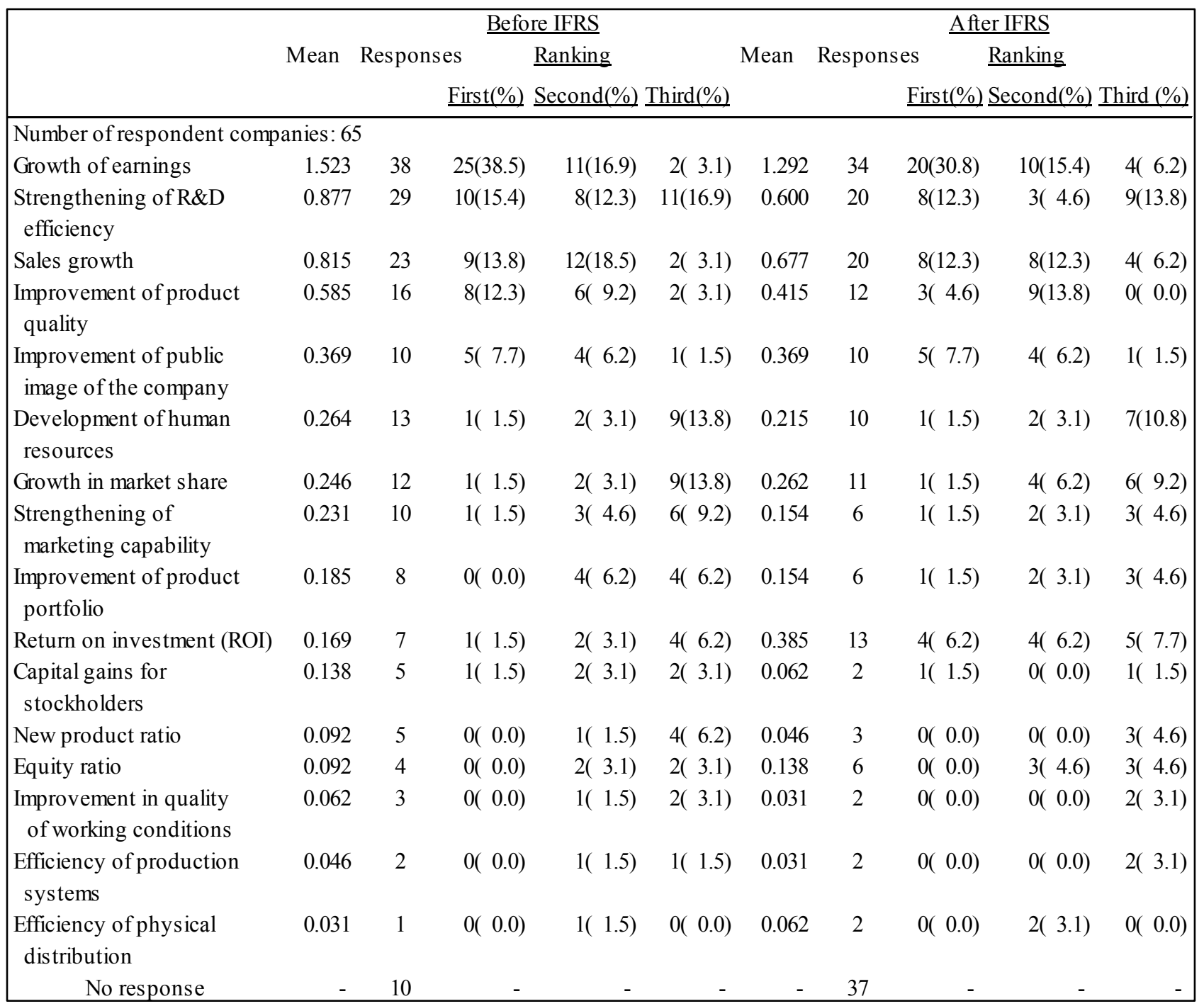

Result of test means difference; $\mathrm{t}$-value $=1.8237$; $\mathrm{p}$-value $=0.0441$. Significant at 5 percent level.

Wilcoxon rank sum test; $z$-value $=2.0447$. $p$-value $=0.0409$. Significant at 5 percent level.

The mean scores in the table are calculated as follows: 3 points for the most important goal, 2 for the second, and 1 for the third. For each item, the points are multiplied by the associated number of responses, and the weighted scores are aggregated and divided by 65 , the number of responding companies. The percentages are the ratio of the number of industry firms surveyed, to the number of responding companies.

\subsection{Financial Measures}

In the same way as strategy goals, financial measures are clarified in this section. How each financial measure was valued before IFRS adoption is shown in Table 3 based on the Likert scale ( 5 is greatly used, 1 is greatly not used). The chi-square test (test of independence) was carried out in order to verify whether the degree of strengthening of financial measures of Japanese companies differs. As a result, it was confirmed that the null hypothesis "There was no difference between the valued financial measures" was rejected, and the alternative hypothesis was significant at 1 percent level and was supported.

Table 4 depicts the comparisons of the two questions. One question is regarding choosing three high ranks of financial measures that have been valued before IFRS introduction, and the other concerns choosing three high ranks of financial measures valued after IFRS introduction. It is shown that neither the t-test nor the Wilcoxon test became significant. As a result of doing the Test (t-test) of the difference of mean of two groups with correspondence and Wilcoxon code ranking sum test based on the sample. As a result of the t-test of the difference of mean of two groups and the Wilcoxon code ranking sum test, the null hypothesis "There will not be any difference in the valued financial measures before and after IFRS adoption" was not proven significant. Here, t-value shows the statistic of the test of the difference of the mean of two groups, and the z-value shows the statistic of the Wilcoxon test, which tests the significance. Thus, it was not able to confirm that the two tests were together significant. This shows that there is no difference at the valuing level of financial measures between before and after IFRS adoption. Japanese companies that refrain from IFRS introduction in 
the near future should clarify measures that are not only a motivation of the action that suits the objective of the organization to the manager, but should also support various processes. Thus, the performance management system that bears an appropriate performance measurement and evaluation is necessary and indispensable. Further, we should construct an accounting system that measures and evaluates useful financial performances for the financial reporting of an outside stakeholder.

Next, this section will qualitatively observe Tables 3 and 4 . First, the item of 25 kinds of financial measures was enumerated, and how each target was used was asked for each measure of the enterprise by a three-stage evaluation (1-3 Likert scale) in the question investigation vote. The evaluation of each used measure was requested to be shown by the figure. Table 3 shows the result. Table 4 depicts the ranking valued about the top three among financial measures of the performance measurement. It shows corporate numbers and ratios according to which a specific financial measure is ranked. In Table 4, it is shown that sales volume, operating profit margin, gross margin, and growth of earnings, etc. each have a high rank. In Japan, it tends for sales volume and operating profit margin, etc. to be valued still because performance measurement is information that forecasts the performance level of all company objectives of the organization. However, the point that should be focused on by this investigation is to locate the profit or the rate of profit in the high rank, including operating profit margin. The "rate of profit" will show the efficiency of management in valued performance measures in the future now, although the performance measures that the companies value are quantitative measures that show the results of amount of profit and sales volume, etc. This shows evidence to emphasize the managerial efficiency when companies plan the management strategy.

When IFRS is applied, this study will provide as an example that an important mean arose especially about strategic goals that the enterprise chose to be a high rank. That is, they are profit margin on sales $\left(3^{\text {rd }}\right.$ rank from $5^{\text {th }}$ rank), cash flow ( $6^{\text {th }}$ rank from $11^{\text {th }}$ rank), return on equity $\left(14^{\text {th }}\right.$ rank from $18^{\text {th }}$ rank), assets turnover $\left(17^{\text {th }}\right.$ rank from $22^{\text {nd }}$ rank), and residual income $\left(17^{\text {th }}\right.$ rank from $22^{\text {nd }}$ rank $)$, etc.

Table 3. Use of Financial Measures

\begin{tabular}{|c|c|c|c|c|c|}
\hline & $\begin{array}{c}\text { Greatly } \\
\text { not used (\%) } \\
1\end{array}$ & $\begin{array}{c}\text { Moderately } \\
\text { used (\%) } \\
2 \\
\end{array}$ & $\begin{array}{c}\text { Greatly } \\
\text { used }(\%) \\
3 \\
\end{array}$ & Mean & $\begin{array}{l}\text { Standard } \\
\text { deviation }\end{array}$ \\
\hline Sales volume & $1(1.5)$ & $3(4.6)$ & $61(93.8)$ & 2.923 & 0.319 \\
\hline Operating profit margin & $1(1.5)$ & $12(18.5)$ & $52(80.0)$ & 2.785 & 0.447 \\
\hline Sales growth & $4(6.2)$ & 24(36.9) & $37(56.9)$ & 2.508 & 0.611 \\
\hline Gross margin & $6(9.2)$ & $17(26.2)$ & $41(63.1)$ & 2.508 & 0.726 \\
\hline Cash flow & $8(12.3)$ & $17(26.2)$ & $40(61.5)$ & 2.492 & 0.704 \\
\hline Inventory level & $9(13.8)$ & $18(27.7)$ & $38(58.5)$ & 2.446 & 0.724 \\
\hline Profit margin on sales (pretax) & $8(12.3)$ & $23(35.4)$ & $34(52.3)$ & 2.400 & 0.697 \\
\hline Growth of earnings & $8(12.3)$ & $23(35.4)$ & $34(52.3)$ & 2.400 & 0.697 \\
\hline Equity ratio & $13(20.0)$ & $26(40.0)$ & $26(40.0)$ & 2.200 & 0.748 \\
\hline Quality cost & $13(20.0)$ & 29(44.6) & $23(35.4)$ & 2.154 & 0.728 \\
\hline Contribution margin & $17(26.2)$ & $21(32.3)$ & $26(40.0)$ & 2.108 & 0.843 \\
\hline Return on owners' equity & 11(16.9) & $36(55.4)$ & $18(27.7)$ & 2.108 & 0.659 \\
\hline Cost variance & $17(26.2)$ & $25(38.5)$ & $23(35.4)$ & 2.092 & 0.779 \\
\hline Financing & $23(35.4)$ & $14(21.5)$ & $28(43.1)$ & 2.077 & 0.882 \\
\hline Return on assets (ROA) & $12(18.5)$ & $38(58.5)$ & $15(23.1)$ & 2.046 & 0.643 \\
\hline Return on equity (ROE) & $16(24.6)$ & $33(50.8)$ & $16(24.6)$ & 2.000 & 0.702 \\
\hline Return on investment (ROI) & $12(18.5)$ & $42(64.6)$ & 11(16.9) & 1.985 & 0.595 \\
\hline Controllable profit & $24(36.9)$ & $20(30.8)$ & $19(29.2)$ & 1.862 & 0.875 \\
\hline Assets turnover & $21(32.3)$ & $32(49.2)$ & $12(18.5)$ & 1.862 & 0.699 \\
\hline Sales per employee & $24(36.9)$ & $31(47.7)$ & $10(15.4)$ & 1.785 & 0.690 \\
\hline Rate of return on assets & $27(41.5)$ & $29(44.6)$ & $9(13.8)$ & 1.723 & 0.691 \\
\hline Cost per employee & $31(47.7)$ & $27(41.5)$ & $7(10.8)$ & 1.631 & 0.670 \\
\hline $\begin{array}{l}\text { Profit on economic measures } \\
\text { (price earnings ratio, etc.) }\end{array}$ & $31(47.7)$ & $28(43.1)$ & $6(9.2)$ & 1.615 & 0.649 \\
\hline Economic value added (EVA) & $35(53.8)$ & 24(36.9) & $6(9.2)$ & 1.554 & 0.657 \\
\hline Residual income & $44(67.7)$ & $17(26.2)$ & $4(6.2)$ & 1.385 & 0.600 \\
\hline Others & $2(3.1)$ & $3(4.6)$ & $1(1.5)$ & 0.169 & 0.570 \\
\hline
\end{tabular}

Result of test of independence: Chi-square value $=484.4810$. Degrees of freedom $=50$. $p$-value $=0.000$. Cramer $V=0.3859$. Significant at 1 percent level. 
Table 4. Importance of Financial Measures between before and after IFRS Adoption

\begin{tabular}{|c|c|c|c|c|c|c|c|c|c|c|}
\hline & \multicolumn{6}{|c|}{ Before IFRS } & \multicolumn{4}{|c|}{ After IFRS } \\
\hline & \multirow[t]{2}{*}{ Mean } & \multirow{2}{*}{ Response } & & \multicolumn{2}{|l|}{$\underline{\text { Ranking }}$} & \multirow[t]{2}{*}{ Mean } & \multicolumn{2}{|c|}{ Responses } & \multicolumn{2}{|l|}{$\underline{\text { Ranking }}$} \\
\hline & & & First $(\%)$ & $\underline{\text { Second }(\%)}$ & Third(\%) & & & First $(\%)$ & cond $(\%)$ & Third(\%) \\
\hline Sales volume & 1.492 & 41 & $22(33.8)$ & $12(18.5)$ & $7(10.8)$ & 0.908 & 27 & $11(16.9)$ & $10(15.4)$ & $6(9.2)$ \\
\hline Operating profit margin & 0.985 & 31 & 11(16.9) & $11(16.9)$ & $9(13.8)$ & 0.723 & 21 & $9(13.8)$ & $8(12.3)$ & $4(6.2)$ \\
\hline Gross margin & 0.508 & 17 & $3(4.6)$ & $10(15.4)$ & $4(6.2)$ & 0.354 & 11 & $3(4.6)$ & $6(9.2)$ & $2(3.1)$ \\
\hline Growth of earnings & 0.415 & 13 & $5(7.7)$ & $4(6.2)$ & $4(6.2)$ & 0.262 & 9 & $3(4.6)$ & $2(3.1)$ & $4(6.2)$ \\
\hline Profit margin on sales (pretax) & 0.369 & 12 & $4(6.2)$ & $4(6.2)$ & $4(6.2)$ & 0.400 & 11 & $6(9.2)$ & $3(4.6)$ & $2(3.1)$ \\
\hline Cash flow & 0.308 & 14 & $1(1.5)$ & $4(6.2)$ & $9(13.8)$ & 0.308 & 14 & $2(3.1)$ & $2(3.1)$ & $10(15.4)$ \\
\hline Sales growth & 0.292 & 8 & $3(4.6)$ & $5(7.7)$ & $0(0.0)$ & 0.215 & 6 & $3(4.6)$ & $2(3.1)$ & $1(1.5$ \\
\hline Return on owr & 0.292 & 10 & $4(6.2)$ & $1(1.5)$ & $5(7.7)$ & 0.262 & 10 & $1(1.5)$ & $5(7.7)$ & $4(6.2)$ \\
\hline Controllable profit & 0.231 & 7 & $3(4.6)$ & $2(3.1)$ & $2(3.1)$ & 0.231 & 7 & $3(4.6)$ & $2(3.1)$ & $2(3.1)$ \\
\hline Contribution margin & 0.215 & 6 & $3(4.6)$ & $2(3.1)$ & $1(1.5)$ & 0.231 & 6 & $3(4.6)$ & $3(4.6)$ & $0(0.0)$ \\
\hline ts (ROA) & 0.169 & 6 & $1(1.5)$ & $3(4.6)$ & $2(3.1)$ & 0.292 & 9 & $4(6.2)$ & $2(3.1)$ & $3(4.6)$ \\
\hline Return & 0.138 & 4 & $1(1.5)$ & $3(4.6)$ & $0(0.0)$ & 0.215 & 6 & $3(4.6)$ & $2(3.1)$ & $1(1.5$ \\
\hline Equity ratio & 0.123 & 6 & $0(0.0)$ & $2(3.1)$ & $4(6.2)$ & 0.077 & 4 & $0(0.0)$ & $1(1.5)$ & $3(4.6$ \\
\hline Financing & 0.077 & 3 & $1(1.5)$ & $0(0.0)$ & $2(3.1)$ & 0.031 & 2 & $0(0.0)$ & $0(0.0)$ & $2(3.1$ \\
\hline Inventory level & 0.046 & 3 & $0(0.0)$ & $0(0.0)$ & $3(4.6)$ & 0.046 & 3 & $0(0.0)$ & $0(0.0)$ & $3(4.6)$ \\
\hline Quality cost & 0.031 & 2 & $0(0.0)$ & $0(0.0)$ & $2(3.1)$ & 0.000 & 0 & $0(0.0)$ & $0(0.0)$ & $0(0.0)$ \\
\hline Cost variance & 0.031 & 1 & $0(0.0)$ & $1(1.5)$ & $0(0.0)$ & 0.031 & 1 & $0(0.0)$ & $1(1.5)$ & $0(0.0$ \\
\hline Rate of return c & 0.015 & 1 & $0(0.0)$ & $0(0.0)$ & $1(1.5)$ & 0.031 & 1 & $0(0.0)$ & $1(1.5)$ & $0(0.0)$ \\
\hline Return on equity (ROE) & 0.015 & 1 & $0(0.0)$ & $0(0.0)$ & $1(1.5)$ & 0.077 & 2 & $1(1.5)$ & $1(1.5)$ & $0(0.0$ \\
\hline Economic value added (EVA) & 0.015 & 1 & $0(0.0)$ & $0(0.0)$ & $1(1.5)$ & 0.062 & 2 & $0(0.0)$ & $2(3.1)$ & $0(0.0)$ \\
\hline Sales per employee & 0.015 & 1 & $0(0.0)$ & $0(0.0)$ & $1(1.5)$ & 0.015 & 1 & $0(0.0)$ & $0(0.0)$ & $1(1.5$ \\
\hline Residual income & 0.000 & 0 & $0(0.0)$ & $0(0.0)$ & $0(0.0)$ & 0.031 & 1 & $0(0.0)$ & $1(1.5)$ & $0(0.0)$ \\
\hline Assets turnover & 0.000 & 0 & $0(0.0)$ & $0(0.0)$ & $0(0.0)$ & 0.031 & 2 & $0(0.0)$ & $0(0.0)$ & $2(3.1)$ \\
\hline Cost per employee & 0.000 & 0 & $0(0.0)$ & $0(0.0)$ & $0(0.0)$ & 0.000 & 0 & $0(0.0)$ & $0(0.0)$ & $0(0.0$ \\
\hline $\begin{array}{l}\text { Profit on economic measures } \\
\text { (price earnings ratio, etc.) }\end{array}$ & 0.000 & 0 & $0(0.0)$ & $0(0.0)$ & $0(0.0)$ & 0.015 & 1 & $0(0.0)$ & $0(0.0)$ & $1(1.5)$ \\
\hline Others & 0.108 & 3 & $2(3.1)$ & $0(0.0)$ & $1(1.5)$ & 0.108 & 3 & $2(3.1)$ & $0(0.0)$ & $1(1.5)$ \\
\hline No response & 0.108 & 4 & - & - & - & 1.046 & 35 & - & - & \\
\hline
\end{tabular}

Result of test means difference: $\mathrm{t}$-value $=1.3888$. $\mathrm{p}$-value $=0.0886$. No significance.

Wilcoxon rank sum test: $z$-value $=0.7299$. $p$-value $=0.4654$. No significance.

The mean scores in the table are calculated as follows: 3 points for the most important goal, 2 for the second, and 1 for the third. For each item, the points are multiplied by the associated number of responses, and the weighted scores are aggregated and divided by 65 , the number of responding companies. The percentages are the ratio of the number of industry firms surveyed, to the number of responding companies.

\subsection{Nonfinancial Measures}

Nonfinancial measures are clarified in this section. How each nonfinancial measure was valued before IFRS adoption is shown in Table 5 based on the Likert scale ( 5 is greatly used, 1 is greatly not used). The chi-square test (test of independence) was carried out in order to verify whether the degree of strengthening for nonfinancial measures of Japanese companies differs. As a result, it was confirmed that the null hypothesis "There was no difference between the valued nonfinancial measures" was rejected, and the alternative hypothesis was significant at the 1 percent level and was supported.

Table 6 depicts the comparison of the answers of two questions. One question concerns choosing three high ranks of nonfinancial measures that have been valued before IFRS introduction and the other concerns choosing those valued after. It is shown that it is significant as a result of doing the Test ( $t$-test) of the difference of mean value of two groups with correspondence and Wilcoxson code ranking sum test based on the sample. That is, as a result of the t-test of the difference of the mean value of two groups and the Wilcoxson code ranking sum test, the null hypothesis "There will not be any difference in the valued nonfinancial measures before and after the introduction of IFRS" was rejected at the 1 percent level of significance by the t-test, and rejected at the 5 percent level of significance by the Wilcoxson test. Here t-value shows the statistic of the test of the difference of the mean of two groups, and the z-value shows the statistic of the Wilcoxson test, which tests the significance. Thus, it was confirmed that the two tests were together significant at the 5 percent level. It is shown that there is a difference to some extent in the degree of serious consideration of nonfinancial measures between before and after IFRS introduction.

True corporate value and strength can be measured by including nonfinancial measures in the present accounting measurement system. Moreover, performance evaluation measures on the intelligent property value must be utilized in strategic decision making and budgeting of companies in order to carry out effective management and proper resource allocation. Our attempt is not only to rely on financial 
measures but also to add the element of nonfinancial measures, and to use it appropriately for strategic judgment as an object of corporate value evaluation.

Next, this section will qualitatively observe Tables 5 and 6 . First, the item of 30 kinds of nonfinancial measures was enumerated, and how each target was used was asked to each measure for the enterprise by a three-stage evaluation (1-3 Likert scale) in the question investigation vote. The evaluation to each used measure was requested to be shown by the figure. Table 5 shows the result. Then, the ranking valued about top three among financial measures of the performance measurement is shown in Table 6 , which shows corporate numbers and ratios in which a specific financial measure is ranked. According to Table 6, growth in market share and prediction of sales growth are relatively valued. As a result, this study puts its focus on valuing for the measures that show non-cost readership strategy like product quality, effect of product development, and ratio of new product to sales, etc. again. Thus, it is difficult to think that the company's management does well even if the accounting evaluation system is constructed without the use of the important nonfinancial measures. In other words, there is a limit in doing the management decision making only by the financial information based on the present insufficient accounting evaluation system. Both financial and nonfinancial measures improved further than the current measures necessary for the manager to evaluate corporate performance. In any case, it was clarified that it was important for companies to establish the new performance evaluation system that put in nonfinancial measures.

When IFRS is applied, this research will emphasize that an important aspect arose especially among strategic goals for which the enterprise had a high rank, as one example. That is to say, they are customer satisfaction $\left(3^{\text {rd }}\right.$ rank from $4^{\text {th }}$ rank), inventory turnover $\left(5^{\text {th }}\right.$ rank from $6^{\text {th }}$ rank $)$, etc.

Table 5. Use of Non-financial Measures

\begin{tabular}{|c|c|c|c|c|c|}
\hline & $\begin{array}{c}\text { Greatly } \\
\text { not used }(\%) \\
1\end{array}$ & $\begin{array}{c}\text { Moderately } \\
\text { used }(\%) \\
2\end{array}$ & $\begin{array}{c}\text { Greatly } \\
\text { used (\%) } \\
3\end{array}$ & Mean & $\begin{array}{l}\text { Standard } \\
\text { deviation }\end{array}$ \\
\hline Product quality & $10(15.4)$ & $23(35.4)$ & $32(49.2)$ & 2.338 & 0.729 \\
\hline Effort to achieve goals & $8(12.3)$ & $24(36.9)$ & $32(49.2)$ & 2.338 & 0.750 \\
\hline Customer satis faction & $6(9.2)$ & $32(49.2)$ & $27(41.5)$ & 2.323 & 0.635 \\
\hline Growth in market share & $9(13.8)$ & $30(46.2)$ & $26(40.0)$ & 2.262 & 0.686 \\
\hline Inventory turnover & $11(16.9)$ & $27(41.5)$ & $27(41.5)$ & 2.246 & 0.724 \\
\hline Ratio of distribution expense to sales & $11(16.9)$ & $36(55.4)$ & $18(27.7)$ & 2.108 & 0.659 \\
\hline Effort to achieve production planning & $20(30.8)$ & $19(29.2)$ & $26(40.0)$ & 2.092 & 0.836 \\
\hline $\begin{array}{l}\text { Total factor (labor, equipment, and } \\
\text { raw material, etc.) productivity }\end{array}$ & $14(21.5)$ & $32(49.2)$ & $19(29.2)$ & 2.077 & 0.708 \\
\hline Prediction of sales growth & $15(23.1)$ & $28(43.1)$ & $21(32.3)$ & 2.062 & 0.782 \\
\hline Effect of product development & $16(24.6)$ & $29(44.6)$ & $19(29.2)$ & 2.015 & 0.774 \\
\hline Engineering level (defect rates) & $19(29.2)$ & $27(41.5)$ & $18(27.7)$ & 1.954 & 0.793 \\
\hline Ratio of new product to sales & $18(27.7)$ & $30(46.2)$ & $15(23.1)$ & 1.892 & 0.787 \\
\hline Development of human resources & $21(32.3)$ & $28(43.1)$ & $15(23.1)$ & 1.877 & 0.775 \\
\hline Output (performance) for one day & $24(36.9)$ & $26(40.0)$ & $15(23.1)$ & 1.862 & 0.762 \\
\hline $\begin{array}{l}\text { Production engineering capability } \\
\text { (e.g., process innovation) }\end{array}$ & $18(27.7)$ & $33(50.8)$ & $12(18.5)$ & 1.846 & 0.749 \\
\hline $\begin{array}{l}\text { Register number of industrial property } \\
\text { (e.g., intellectual es tate productivity) }\end{array}$ & $20(30.8)$ & $30(46.2)$ & $13(20.0)$ & 1.831 & 0.776 \\
\hline Degree of global environment protection & $22(33.8)$ & $30(46.2)$ & $12(18.5)$ & 1.815 & 0.742 \\
\hline Human cost-benefit & $20(30.8)$ & $34(52.3)$ & $10(15.4)$ & 1.815 & 0.699 \\
\hline Ratio of R\&D cost to sales & $27(41.5)$ & $25(38.5)$ & $13(20.0)$ & 1.785 & 0.754 \\
\hline R\&D capability of technological experts & $23(35.4)$ & $30(46.2)$ & $11(16.9)$ & 1.785 & 0.734 \\
\hline Important technique holding degree & $24(36.9)$ & $29(44.6)$ & $11(16.9)$ & 1.769 & 0.739 \\
\hline Safety & $26(40.0)$ & $25(38.5)$ & $12(18.5)$ & 1.723 & 0.794 \\
\hline $\begin{array}{l}\text { Jidoka of production } \\
\text { (i.e., manufacturing automation) }\end{array}$ & $25(38.5)$ & $33(50.8)$ & $6(9.2)$ & 1.677 & 0.659 \\
\hline Efficiency of equipment & $32(49.2)$ & $30(46.2)$ & $2(3.1)$ & 1.508 & 0.585 \\
\hline Intangible ass ets & $35(53.8)$ & $28(43.1)$ & $1(1.5)$ & 1.446 & 0.556 \\
\hline Return on investment to $R \& D$ & $37(56.9)$ & $25(38.5)$ & $2(3.1)$ & 1.431 & 0.581 \\
\hline Order number (value) of R\&D & $38(58.5)$ & $21(32.3)$ & $4(6.2)$ & 1.415 & 0.654 \\
\hline Reduction of labor turnover & $43(66.2)$ & $20(30.8)$ & $2(3.1)$ & 1.369 & 0.543 \\
\hline Balanced scorecard & $43(66.2)$ & $14(21.5)$ & $6(9.2)$ & 1.369 & 0.692 \\
\hline Sales according to distributors & $45(69.2)$ & $14(21.5)$ & $5(7.7)$ & 1.354 & 0.643 \\
\hline Others & $6(9.2)$ & $1(1.5)$ & $0(0.0)$ & 0.123 & 0.372 \\
\hline
\end{tabular}

Result of test of independence: Chi-square value $=352.5919$. Degrees of freedom $=60$. $p$-value $=0.000$. Cramer $V=0.3022$. Significant at 1 percent level. 
Table 6. Importance of Non-financial Measures between before and after IFRS Adoption

\begin{tabular}{|c|c|c|c|c|c|c|c|c|c|c|}
\hline & \multicolumn{6}{|c|}{ Before IFRS } & \multicolumn{4}{|c|}{ After IFRS } \\
\hline & \multirow[t]{2}{*}{ Mean } & \multicolumn{2}{|c|}{ Responses } & \multicolumn{2}{|l|}{$\underline{\text { Ranking }}$} & \multirow[t]{2}{*}{ Mean } & \multicolumn{2}{|c|}{ Responses } & \multicolumn{2}{|l|}{$\underline{\text { Ranking }}$} \\
\hline & & & $\underline{\text { First }(\%)}$ & econd $(\%)$ & hird $(\%)$ & & & $\underline{\text { First( }(\%)}$ & ond $(\%)$ & hird $(\%)$ \\
\hline Growth in & 0.969 & 27 & $16(24.6)$ & $4(6.2)$ & $7(10.8)$ & 0.815 & 22 & $13(20.0)$ & $5(7.7)$ & $4(6.2)$ \\
\hline Product quality & 0.862 & 2 & $10(15.4)$ & $11(16.9)$ & $4(6.2)$ & 0.615 & 18 & $7(10.8)$ & $8(12.3)$ & $3(4.6$ \\
\hline Prediction of sales growth & 0.492 & 14 & $6(9.2)$ & $6(9.2)$ & $2(3.1)$ & 0.415 & 12 & $5(7.7)$ & $5(7.7)$ & $2(3.1)$ \\
\hline Customer satis faction & 0.477 & 14 & $7(10.8)$ & $3(4.6)$ & $4(6.2)$ & 0.508 & 13 & $8(12.3)$ & $4(6.2)$ & $1(1.5)$ \\
\hline Effect of product develo & 0.431 & 14 & $5(7.7)$ & $4(6.2)$ & $5(7.7)$ & 0.200 & 7 & $2(3.1)$ & $2(3.1)$ & $3(4.6$ \\
\hline Effort to achieve goals & 0.385 & 13 & $5(7.7)$ & $2(3.1)$ & $6(9.2)$ & 0.323 & 11 & $4(6.2)$ & $2(3.1)$ & $5(7.7$ \\
\hline Inventory & 0.308 & 10 & $3(4.6)$ & $4(6.2)$ & $3(4.6)$ & 0.323 & 11 & $3(4.6)$ & $4(6.2)$ & $4(6.2)$ \\
\hline Ratio of distribution & 0.262 & 10 & $1(1.5)$ & $5(7.7)$ & $4(6.2)$ & 0.215 & 8 & $2(3.1)$ & $2(3.1)$ & $4(6.2$ \\
\hline Effort & 0.185 & 7 & $0(0.0)$ & $5(7.7)$ & $2(3.1)$ & 0.077 & 3 & $0(0.0)$ & $2(3.1)$ & $1(1$. \\
\hline $\begin{array}{r}\text { Total factor (labor, ec } \\
\text { raw material, etc.) pr }\end{array}$ & 0.169 & 6 & $2(3.1)$ & $1(1.5)$ & $3(4.6)$ & 0.123 & 5 & $1(1.5)$ & $1(1.5)$ & $3(4$. \\
\hline Ratio of new $\mathrm{p}$ & 0 . & 6 & $1(1.5)$ & $2(3.1)$ & $3(4.6)$ & 0 . & 6 & $1(1.5)$ & $2(3.1)$ & $3(4$. \\
\hline Engine & 0.154 & 6 & $0(0.0)$ & $4(6.2)$ & $2(3.1)$ & 0.092 & 3 & $0(0.0)$ & $3(4.6)$ & $0(0.0$ \\
\hline Outpu & 0.108 & 4 & $1(1.5)$ & $1(1.5)$ & $2(3.1)$ & 0.046 & 2 & $0(0.0)$ & $1(1.5)$ & $1(1.5$ \\
\hline Balance & 0.092 & 2 & $2(3.1)$ & $0(0.0)$ & $0(0.0)$ & 0.108 & 3 & $2(3.1)$ & $0(0.0)$ & $1(1.5$ \\
\hline Ratio o & 0.077 & 2 & $1(1.5)$ & $1(1.5)$ & $0(0.0)$ & 0.092 & 3 & $1(1.5)$ & $1(1.5)$ & $1(1$. \\
\hline $\begin{array}{l}\text { Production engineering capability } \\
\text { (e.g., process innovation) }\end{array}$ & 0. & 3 & $0(0.0)$ & $2(3.1)$ & .5) & 0.000 & 0 & $0(0.0)$ & $0(0.0)$ & $0(0$. \\
\hline Safety & 0.077 & 3 & $0(0.0)$ & $2(3.1)$ & 1( & 0.062 & 2 & $0(0.0)$ & $2(3.1)$ & $0(0.0$ \\
\hline $\begin{array}{l}\text { Degree of global environment } \\
\text { protection }\end{array}$ & 0.062 & 2 & $1(1.5)$ & $0(0.0)$ & $1(1.5)$ & 0.062 & 2 & $1(1.5)$ & $0(0.0)$ & $1(1$. \\
\hline $\begin{array}{l}\text { R\&D capability of technological } \\
\text { experts }\end{array}$ & 6 & 2 & $(0.0)$ & $1(1.5)$ & 5) & 0.046 & 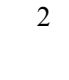 & $0(0.0)$ & $1(1.5)$ & $1(1$ \\
\hline Sales according to & 0.046 & 2 & $0(0.0)$ & $1(1.5)$ & $1(1.5)$ & 0.031 & 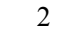 & $0(0.0)$ & $0(0.0)$ & $2(3.1$ \\
\hline t to $R \& D$ & 0.031 & 2 & $0(0.0)$ & $0(0.0)$ & $2(3.1)$ & 0.077 & 3 & $1(1.5)$ & $0(0.0)$ & $2(3$. \\
\hline Import: & 0.031 & 1 & $0(0.0)$ & $1(1.5)$ & $0(0.0)$ & 0.046 & 2 & $0(0.0)$ & $1(1.5)$ & $1(1$. \\
\hline Development of hum & 0.031 & 2 & $0(0.0)$ & $0(0.0)$ & $2(3.1)$ & 0.062 & 3 & $0(0.0)$ & $1(1.5)$ & $2(3$. \\
\hline cost-benefit & 0.015 & 1 & $0(0.0)$ & $0(0.0)$ & $1(1.5)$ & 0.000 & 0 & $0(0.0)$ & $0(0.0)$ & $0(0.0$ \\
\hline Intar & & 1 & $0(0.0)$ & $0(0.0)$ & & 0.015 & 1 & $0(0.0)$ & $0(0.0)$ & $1(1$. \\
\hline $\begin{array}{l}\text { Jidoka of production } \\
\text { (i.e., manufacturing automation) }\end{array}$ & 0.015 & 1 & $0(0.0)$ & $0(0.0)$ & $1(1.5)$ & 0.031 & 1 & $0(0.0)$ & $1(1.5)$ & $0(0$. \\
\hline Order number (value) of R\&D & 0.000 & 0 & $0(0.0)$ & $0(0.0)$ & & 0.000 & 0 & $0(0.0)$ & $0(0.0)$ & $0(0$. \\
\hline $\begin{array}{r}\text { Register number of industrial property } \\
\text { (e.g., intellectual estate productivity) }\end{array}$ & 0.000 & 0 & $0(0.0)$ & $0(0.0)$ & $0(0.0)$ & 0.000 & 0 & $0(0.0)$ & $0(0.0)$ & $0(0.0$ \\
\hline Efficiency of equipment & 0.000 & 0 & $0(0.0)$ & $0(0.0)$ & $0(0.0)$ & 0.000 & 0 & $0(0.0)$ & $0(0.0)$ & $0(0.0)$ \\
\hline of labor turnover & 0.000 & 0 & $0(0.0)$ & $0(0.0)$ & $0(0.0)$ & 0.000 & 0 & $0(0.0)$ & $0(0.0)$ & $0(0.0$ \\
\hline Others & 0.000 & 0 & $0(0.0)$ & $0(0.0)$ & $0(0.0)$ & 0.000 & 0 & $0(0.0)$ & $0(0.0)$ & $0(0.0)$ \\
\hline No response & 0.431 & 15 & 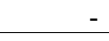 & - & 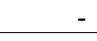 & 1.446 & 48 & - & & \\
\hline
\end{tabular}

Result of test means difference; $t$-value $=2.7974$. $\mathrm{p}$-value $=0.0049$. Significant at 1 percent level.

Wilcoxon rank sum test; z-value $=2.1899$. $p$-value $=0.0285$. Significant at 5 percent level.

The mean scores in the table are calculated as follows: 3 points for the most important goal, 2 for the second, and 1 for the third. For each item, the points are multiplied by the associated number of responses, and the weighted scores are aggregated and divided by 65 , the number of responding companies. The percentages are the ratio of the number of industry firms surveyed to the number of responding companies.

\section{Summary and Conclusions}

This paper searches for the trend and the feature concerning IFRS, and has analyzed what influence the introduction of IFRS exerts on the business strategy and performance measures of management accounting. Specifically, after introducing IFRS, the findings in this study clarified how the importance of strategic goals of the companies, financial measures, and nonfinancial measures change through the mailing question investigation to Japanese companies, and did empirical analyses on how
IFRS influenced various measures. It is thought that the clarification of the hypothesis concerning some performance evaluation systems through a statistical verification contributes to IFRS measures of Japanese manufacturing companies in the future. It is understood that the adoption of IFRS becomes an extremely strategic accounting initiative for Japanese companies as a result of the analysis.

As the features of IFRS, the conversion to the approach of (1) principle base, (2) assets-liabilities approach, and (3) fair value accounting can be pointed out. Specifically, if IFRS is introduced, comprehensive income will be adopted as the 
main performance measure, although Japanese companies have taken the standpoint where the final achievement is displayed by net profit up to now. Therefore, it is necessary to reflect the profit of the stock that shows market quotation of the property that the enterprise has. In short, the comprehensive income comprises the addition of the change of fair value of the cross-holding of shares and the change of the exchange of net assets, etc. the overseas subsidiary had to net profit. Specifically, such a new income concept of IFRS is an idea assumed to be "Value change of the risk property by which the cash flow that the enterprise will invent in the future influences it"[11]. ${ }^{18}$

By IFRS adoption, evaluation and measurement rule of the corporate performance may greatly change. Of course, sales of the product shift from shipment standard to arrival standard of goods, and selection application for depreciation is admitted. However, several restrictions exist, as it will be necessary to forecast the economic convenience in the future of the property. On the other hand, it is likely to arise also from the advantage of becoming easy to grasp and compare financial situations of companies by using a common standard and easy to make a funding, M\&A in foreign countries or a strategic plan.

Consequently, the possibility that the change appears obviously is incontrovertible to the current corporate strategy and performance evaluation. In this paper, being possible to verify it statistically was an important discovery when there was a difference in corporate strategic goals and performance measurement measures after IFRS adoption. Surely, assuming the importance of corporate strategic goals, financial measures, and nonfinancial measures changed before and after IFRS adoption and having analyzed it were significant. As a result, it was not confirmed that the tendency (difference) to value financial measures after IFRS adoption was statistically significant. However, there is a significant meaning in the implication of this study that the hypothesis about strategic goals and non-financial measures was obviously supported.

It is necessary to examine IFRS carefully to understand what influence is exerted on the accounting practice by its introduction, not only with respect to strategic goals and performance measurement measures, but also for other management accounting techniques such as capital investment and budgeting, or research and development (R\&D) investment and international taxation, etc. A further study regarding IFRS should be conducted as potential research subjects in the future.

18 Nikkei Business $(2010,26)$. By introducing IFRS, net income and income before extraordinary items disappears from the financial statements of Japanese companies, and a new income concept of comprehensive income will be displayed as one of the features. It comes for the enterprise to make the financial position more conspicuous, and to accomplish a new accountability to the management result by using this income concept.

\section{Data Availability}

Data pertaining to the individual firms used in this study cannot be made public due to confidentiality agreements with respondent firms.

\section{Acknowledgements}

I appreciate the helpful comments of the seminar participants at Ritsumeikan University, Nagoya City University in Japan. I also benefited from discussions with session participants at $27^{\text {th }}$ Asian-Pacific Conference on International Accounting Issues. This work was supported by Grant-in-Aid for Scientific Research (C) of JSPS KAKENHI Grant Number 16K04016.

\section{REFERENCES}

[1] International Accounting Standards Board (2004), 2004 International Financial Reporting Standards (IFRS), International Accounting Standards Committee Foundation (IASCF) Publications Department.

[2] SEC (2008a), Roadmap for the potential use of financial statements prepared in accordance with International Financial Reporting Standards by U.S. issuers. 1-165. http://www.sec.gov/rulus/proposed/2008/33-8982.pdf.

[3] SEC (2010b), Commission Statement in Support of Convergence and Global Accounting Standards, (Release No. 33-9190; 34-61578), February 24: 1-42.

[4] IASC (2010), International Accounting Standards Committee (IASC) Foundation Constitution, IASB, March 2010. (Approved January 2010, Updated December 2010): 1-20. http://www.iasplus.com/en/Plone/en/binary/iascf/1003constit ution.pdf

[5] Japan Financial Services Agency (JFSA) (2009), Application of International Financial Reporting Standards (IFRS) in Japan (Summary), Tentative and Unofficial Summary by JFSA Staff, June 12:1-4.

[6] Corporate Accounting's editorial staff (2012), The Interview to Prof. Tsujiyama: Where Does the Accounting Standard of Our Country Approach?, Corporate Accounting (Kigyo Kaikei) 64(5):69-79. [In Japanese].

[7] Tsujiyama, E. (2011). Globalization of Accounting Standards and Meta-Rule of Accounting Standards, Corporate Accounting (Kigyo Kaikei), 179(1): 69-79. [In Japanese].

[8] Kagaya, T. (2012), Has the Convergence to the IFRS Affected Investment Behavior?: International Evidences, Hitotsubashi Business Review, Sum. 60(1): 38-56. [In Japanese].

[9] Hoshino, Y. (2013), Strategy Goals, Financial and Nonfinancial Measures, and Performance Evaluation in Japanese Manufacturing Companies, The Journal of Management Accounting, Japan Supplement, 2: 121-138.

[10] Hoshino, Y. (2012), An Influence of IFRS on Japan's Institutional Accounting, The Journal of International and 
Regional Economics, 13:39-49. [in Japanese].

[11] Nikkei Business (2010), The Japanese management which IFRS Destroys: The Enterprise which Worries about the New Profit Concept, Nikkei Business, June 7: 23-37. [In Japanese].

[12] Cohen, S., and S. Karatzimas (2013), Has IFRS Adoption affected Management Accounting Systems? Empirical Evidence from Greece, International Journal of Accounting, Auditing and Performance Evaluation, 9(3): 268-285.

[13] Prochazka, D. (2009), The Development of Financial and Management Accounting after the IFRS adoption: A Case from the Czech Republic, (Working Paper $2^{\text {nd }}$ version), Analysis of Accounting Standards for Income Reporting--New Approaches in the World and Possibilities of their Utilization in the Czech Republic, No. GA402/09/P523: 1-36.

[14] Jones, T. C., and R. Luther (2005), Anticipating the Impact of IFRS on the Management of German Manufacturing Companies: Some Observations from a British Perspective, Accounting in Europe, 2(1): 165-193.

[15] Ozkan N., Z. Singer, and H. You (2012), Mandatory IFRS Adoption and the Contractual Usefulness of Accounting Information in Executive Compensation, Journal of
Accounting Research, 50(4): 1077-1107.

[16] Shimizu, T. (2011), The Change of the Viewpoint of Management Accounting by the IFRS Adoption, Corporate Accounting (Kigyo Kaikei), 63(1): 103-109. [In Japanese].

[17] Kawano, K. (2010), Impact of IFRS on Management Accounting, Corporate Accounting (Kigyo Kaikei), 62(6): 24-31. [In Japanese].

[18] Kanagaretnam, K., R. Maethieu, and M. Shehata (2009), Usefulness of Comprehensive Income Reporting in Canada, Journal of Accounting and Policy, 28(4): 349-365.

[19] Sonoda, T. (2011), Impact of IFRS Adoption on Cost Accounting and Management Accounting, Corporate Accounting (Kigyo Kaikei), 63(10): 113-119. [In Japanese].

[20] Sakurai, M. (2012), Impact of IFRS on Theory and Practice of Management Accounting, Accounting (Kaikei), 181(2): 91-108. [In Japanese].

[21] Ueno, S. (2010), An Influence of International Convergence of Accounting Standards on Management Accounting: Firm Performance Measures, Accounting (Kaikei), 177(2): 35-46. [In Japanese]. 